\author{
Andrzej Wegliński ${ }^{1}$ iD http:/orcid. org/0000-0002-2050-5749 \\ Marie Curie Skłodowska University in Lublin
}

\title{
CLASSIFICATION OF CONVICTS UNDER SUPERVISION OF PROBATION OFFICERS TO THE RECIDIVISM RISK GROUPS BASED ON CRIMINOGENIC FACTORS
}

\begin{abstract}
Summary: On the basis of cross-sectional studies estimated were the rules for classification to risk groups of people who were sentenced and under supervision of a probation officer. The classification of probationers into risk groups is meant to enhance the public security and adjust the type and intensity of actions taken by probation officers according to the profile of convicts. It thus became possible to adapt the methodological measures used by probation officers to the work strategies of the worldwide probation services based on the case management model. The adopted solutions are in accordance with the UN Standard Minimum Rules (The Tokyo Rules) and standards included in the European Probation Rules.
\end{abstract}

Keywords: probations officers, probationers, risk groups

\section{Introduction}

The supervision by a probation officer as a reaction to committed crime is intended to resocialize a convict in an open environment, rejecting the idea of retaliation which contradicts the goal of probation. According to the United $\mathrm{Na}$ tions Standard Minimum Rules for Non-custodial Measures (UN Tokyo Rules), the basic goal of probation is giving a necessary assistance to the probationer and

1 Dr hab. Andrzej Węgliński, prof. UMCS, Marie Curie Skłodowska University in Lublin, Institute of Pedagogy; ul. Narutowicza 12, 20-004 Lublin; e-mail: aweglinski@poczta.umcs.lublin.pl. 
inclusion to the society ${ }^{2}$. The probation is connected to various system of suspended sentences. There is: 1) an Anglo-American system with a conditional suspension of a sentence under a probation and supervision by a probation officer; 2) Franco-Belgian system with a suspended sentence in a simple form (sursis simple) without duties and supervision, or with duties and supervision (sursis avec mise a lepreuve); 3) Norwegian-Danish-Dutch system involving a conditional suspension of prosecution for a probation period with duties and supervision ${ }^{3}$.

The resocialization under the conditions of supervised freedom means a case-specific approach by a probation officer to each probationer with a very accurate monitoring and correction of criminogenic factors which have led to the crime. The essence of probation measures involves an assumption of positive individual forecast which correctness is verified during the probation period ${ }^{4} . \mathrm{Im}^{-}$ portant and fundamental changes have taken place in the operation of probation services in recent years. In many countries, the social services model is based on the case management method in which a probation officer becomes an offender manager responsible for ensuring the probationer's access to various aid institutions and programmes and therapies aimed at changing or limiting the criminogenic needs. In addition, the main goal of probation is elimination of criminogenic factors that generate recidivism among convicts 5 .

The priority task of resocialization in an open environment is to protect the public and the probationers against further crimes. For this process to be effective, the probation officers need to be equipped with specific intervention strategies verified by the evidence-based practice. The operation of probation services begins to focus on two tasks: identification of individual recidivism risk factors (risk assessment) and planning and implementation of interventions oriented to risk factors diagnosed in probationers (risk management) ${ }^{6}$.

2 Grażyna Szczygiel, “Środki alternatywne wobec kary pozbawienia wolności”, Nowa Kodyfikacja Prawa Karnego XXXIII. Acta Universitatis Wratislaviensis 3617 (2014).

3 Jan Skupiński, Warunkowe skazanie w prawie polskim na tle porównawczym (Warszawa: Oficyna Naukowa, 1992), 16; Andrzej Marek, Prawo karne (Warszawa: Wydawnictwo C.H. Beck, 2006), 203.

4 Andrzej Kordik, Warunkowe zawieszenie wykonania kary w systemie środków probacyjnych i jego efektywność (Wrocław: Drukarnia Kwant, 1998).

5 Zofia Ostrihanska, "Diagnoza w pracy kuratora sądowego". In: Zarys metodyki pracy kuratora sqqdowego, eds. Tadeusz Jedynak, Krzysztof Stasiak (Warszawa: Wolters Kluwer, 2008); Dobrochna Wójcik, "Stosowanie w postępowaniu karnym narzędzi diagnostyczno-prognostycznych służących oszacowaniu ryzyka powrotności do przestępstwa”, Prawo w Działaniu. Sprawy Karne 16 (2013), 59-102; Maciej Muskała, "Służba kuratorska w Anglii i Walii", Probacja 1 (2015), 51-66.

6 Agnieszka Barczykowska, Sonia Dzierżyńska-Breś, "Profilaktyka oparta na wynikach badań naukowych (evidence based practice)", Resocjalizacja Polska 4 (2013), 131-150; Barbara Stańdo-Kawecka, "Wybrane problemy profesjonalizacji organów probacyjnych i klasyfikacji sprawców oddanych pod dozór do grup ryzyka", Nowa Kodyfikacja Prawa Karnego XXXIII. Acta Universitatis Wratislaviensis 3617 (2014). 
The probation officers focus on identifying the recidivism risk factors which are to be corrected or eliminated during the supervision. The risk factors on one hand determine the likelihood of probationer's relapsing into crime, and on the other hand become an object of resocialization actions. Thus, in the new supervision methodology we deal with assessment and management of risk (needs, criminogenic factors) ${ }^{7}$. Based on numerous practical experiences and empirical tests, the distinguished Canadian psychologists Donald Andrews, James Bonta and Robert Hoge ${ }^{8}$ developed the R-N-R model (risk-need-responsivity) which very quickly became the world's best known method to estimate the recidivism risk and to limit it and resocialize the criminals. The recidivism risk assessment in a specific individual determines the level of intervention by probational officers. According to the model, the correction programmes should be addressed to offenders who have many problem areas correlated with recidivism. The authors of the R-N-R model proved that the effectiveness of rehabilitation programmes depends on the traits of the influence recipient, intensity of criminogenic factors, person's situation at a time. The rehabilitation influences are usually effective for people with medium and high recidivism risk, and limited in case of offenders from the low-risk group. In the case management-based strategy the probation officer's role comes down to: 1) collect information on the criminogenic needs of the probationer; 2) classify a probationer to the appropriate risk group; 3) plan interventions; 4) suggest to the probationer the services adequate to his/her problems; 5) monitor the scope of performed tasks and actions; 6) support the change process and estimate the effects. In the output risk management methodology, the task of probation officers is to collect information on the recidivism risk factors, and then to profile the supervised people to groups differentiated in terms of the probation failure risk measured as the recidivism rate. This means that the probation officers must be equipped with appropriate, reliable, proven and structured recidivism risk estimation tools. In the R-N-R model, the correct diagnosis comes down to a reliable identification of predictors of the probationer's future criminal activity. These factors can be static or dynamic. The static factors can change only in one direction, that is intensify causing the risk to grow. The dynamic factors on the other hand can change in both directions in a specific time and this can affect the offender's behaviour and limit the likelihood of recidivism. The limits of an effective resocialization of probationers are determined by the so-called static risk factors that is empirical predictors of future criminal

7 Donald Andrews, James Bonta, The Psychology of Criminal Conduct (New Providence: Lexis-Nexis 2010), 49; Mariusz Sztuka, Anachronizm i aktualność. Idea resocjalizacji w sporze o nowoczesność (Kraków: Wydawnictwo Uniwersytetu Jagiellońskiego, 2013), 233.

8 Donald Andrews, James Bonta, Robert Hoge, "Classification for Effective Rehabilitation. Rediscovering Psychology”, Criminal Justice and Behavior 17 (1990). 
conduct. Separation and estimation of the intensification of these factors will decide the chances of an effective rehabilitation?.

Recently the Ministry of Justice has attempted to link the programmed resocialization actions in the probation officers' work methodology with the recidivism risk evaluation and the need to classify the probationers to the appropriate recidivism risk group (Regulation of the Minister of Justice, 2013, item 335; Regulation of the Minister of Justice, 2016, item 969; Code of Corrections, Art. 169b). The contents of these laws clearly reflects a new case management-based strategy of probational services, developed within the new approach to rehabilitation called as the What works movement in corrections, aiming at the identification of the conditions of effective corrective interventions. In the English-language literature it is also called the evidence based criminal policy ${ }^{10}$.

According to the valid legal regulations, the probational officers for adults can classify a probationer to one of the three recidivism risk groups: 1) reduced risk (group A); 2) basic (group B); 3) increased risk (group C) (Regulation 2016, item 969; Code of Corrections, Art. 169b). In the Ministry's assumptions, classification of probationers to risk groups is to improve the public security by reducing the recidivism rate among people supervised by probation officers, adapt the type and intensity of the probation officers' actions to the identified risk factors, introduce clear and objective criteria for dividing the cases according to the degree of difficulty (so-called risk groups), improve the probationer's supervision procedures taking into account the appropriate frequency and recommended dates. Classification of probationers to profiled recidivism risk groups is to improve the services management by probation officers and will allow adapting the probation management to the standards included in the European probation rules ${ }^{11}$.

Unfortunately, the probation officers were not equipped with reliable measuring tools for classification to the risk groups. The classification is not based on proven forecasting techniques. A probation officer classifies a probationer to a risk group based on the risk factors arbitrarily chosen by the legislature. During the probationers profiling process, the probation officers take into account two groups of detailed features, namely the subject features that include historical, individual and situational features typical for a probationer, and the object features which include features of offences committed by the probationer, with

9 Andrews, Bonta, The Psychology..., 67; Sztuka, Anachronizm i aktualność..., 233.

10 Barbara Stańdo-Kawecka, "Ruch What works i 'nowa resocjalizacja' - nowa perspektywa w polityce karnej?”. In: Węzłowe problemy prawa karnego, kryminologii i polityki kryminalnej. Księga pamiątkowa ofiarowana Profesorowi Andrzejowi Markowi, eds. Violeta Konarska-Wrzosek, Jerzy Lachowski, Jerzy Wójcikiewicz (Warszawa: Wydawnictwo Wolters-Kluwer, 2010), 901.

11 Eadem, "Wybrane problemy...”; Andrzej Węgliński, "Resocjalizacja w środowisku otwartym z zastosowaniem metody zarządzania przypadkiem w dozorach kuratorskich”. In: Współczesne dylematy resocjalizacyjne - w stronę twórczej resocjalizacji, eds. Wiesław Ambrozik, Anna Kieszkowska, Kazimierz Sawicki (Kraków: Oficyna Wydawnicza "Impuls", 2018). 
particular emphasis on the crimes committed during the probation period. The factors selection procedure specified in the Regulation does not refer to theoretical substantiations or empirical evidence ${ }^{12}$.

A new approach to risk estimation appeared in the 1970s: the actuarial (mathematical, statistical) approach that aimed at an objective process of forecasting the future criminal behaviours by creating tools allowing the determination of a statistical probability of the next crime being committed by a given offender. The actuarial assessment of risk/needs refers to the principal rehabilitation rules according to which the preliminary stage, preceding any activity, is a diagnosis made using the tools and procedures for evaluation of needs and risk ${ }^{13}$. The identification of static risk factors is linked with the case anamnesis, that is a study of something which precedes the states of disease, failure, crisis, otherness, deviation, crime. The anamnesis is an attempt to answer the question: "How long is the period preceding the infringement of the norms or social values?". It can be said that it is an analysis of difficult situations, some individual or environmental toxic factors which precede a crime. The anamnestic studies, that also include an analysis of the individual's life in successive development phases, have the form of biographical life history studies, and the identification of the dynamic risk factors is connected with the case catamnesis that is an analysis of the period in which the first symptoms of social maladjustment and criminal behaviour occurred ${ }^{14}$.

Based on the identified static and dynamic risk factors, the probation officers can make an attempt to forecast the recidivism among the probationers. A criminological forecast is understood as any statement said about future features of criminal phenomena. The crime forecasting is divided into two basic types: 1) forecasting of primary crimes (crimes committed for the first time), and 2) forecasting of return crime (other crimes committed by the offenders who have served their sentences) ${ }^{15}$.

Dividing the offenders supervised by a probation officer into risk groups was supposed to be a milestone in reforming the probation system in Poland to make it similar to the probation in the "nations advanced in terms of civilization". A reliable estimation of the recidivism risk means that probation officers must have standardized tools to recognize criminogenic needs. Since recently we have had the Criminal Behaviour Risk Assessment Forecasting Scale (SPORPZP)

${ }^{12}$ Mariusz Sztuka, "Szacowanie ryzyka w pracy kuratora. Polskie rozwiązania i ich odpowiedniki w rozwiniętych systemach zachodnich”. In: Polska kuratela sądowa na przełomie wieków. Nadzieje, oczekiwania, dylematy, redakcja naukowa, eds. Marek Konopczyński, Łukasz Kwadrans, Krzysztof Stasiak (Kraków: Oficyna Wydawnicza "Impuls", 2016).

${ }^{13}$ Andrews, Bonta, The Psychology...; Wójcik, "Stosowanie w postępowaniu..."

${ }_{14}$ Andrzej Bałandynowicz, "Reintegracja społeczna skazanych wsparta na paradygmacie tożsamości osobowej, społecznej i kulturowo-cywilizacyjnej”, Niepełnosprawność 8 (2012), 9-39.

${ }^{15}$ Brunon Hołyst, "Podstawy i zakres indywidualnej prognozy kryminologicznej", Probacja 1 (2013). 
developed by Brunon Hołyst ${ }^{16}$. The risk factors identified in the SPORPZP will form a basis to collect information on the probationers included in the studies described further in the paper. The source of information about individual static and dynamic risk factors were probation officers responsible for offenders on probation. The recidivism risk estimation model proposed by the cited author can be an interesting alternative to Ministry of Justice's procedure of classifying the convicts to the three risk groups: A - reduced; B - basic; $\mathrm{C}$ - increased (Regulation 2016, item 969; Code of Corrections, Art. 169b). The collected empirical data will allow a comparison of classification to risk groups by probation officers (without a measuring tool, based on negative risk factors developed in the Ministry of Justice) with the classification based on the factors included in the SPORPZP.

As a case manager, the probation officer controls the resocialization process in an open environment, is a person whom the convict can ask come for help, support, intervention, negotiations in situations of conflict $^{17}$. In the case management-based strategy, the probation officer collects information on the probationer's criminogenic needs, classifies the probationer to the appropriate risk group, plans individual interventions, arranges the services in accordance with the probationer's problems, monitors the scope of performed tasks and activities, supports the change process and estimates the effects ${ }^{18}$.

\section{Cognitive Plans}

The basic aim of the studies will be an attempt to identify the static and dynamic recidivism risk factors among the probationers. In addition, it has been decided to verify the conformity of the classification of probationers to risk groups based on negative factors included in the Ministry of Justice documents and the factors identified on the basis of the individual criminological forecast. The recidivism risk level will be determined based on the information obtained from probation officers. The designed studies sought answers to the following detailed questions:

1. What is the family and environmental situation of probationers, including criminogenic factors?

2. What are the features of criminal biography of the probationers supervised by probation officers?

3. What are the traits of character and addiction symptoms of probationers in the view of probation officers?

16 Idem, "Skala Prognostyczna do Oceny Ryzyka Podjęcia Zachowań Przestępczych - indywidualna predykcja kryminologiczna”, Probacja 2 (2013), 43.

17 Agnieszka Smrokowska-Reichmann, "Amerykański Case Management - wzorzec dla reform systemu pomocy społecznej w Polsce?”, Wspólne Tematy 10 (2009).

18 Sztuka, Anachronizm i aktualność... 
4. What are, if any, the differences in classification of probationers to the recidivism risk groups taking into account static and dynamic factors determined in the criminological forecast and the classification based on the criterial laid down in the Ministry of Justice documents?

As the Polish literature on the subject matter does not describe studies on classification of the probationers to the recidivism risk groups with the use of a measuring tool (forecasting scale), in the answer to question four no attempt has been made to formulate a working hypothesis. The remaining questions are of diagnostic-descriptive character and do not require hypotheses.

The recidivism risk factors among the probationers will be assessed using the specially developed survey questionnaire aimed at identification of 29 static and 23 dynamic criminogenic factors distinguished in the Criminal Behaviour Risk Assessment Forecasting Scale (SPORPZP) developed by Brunon Hołyst ${ }^{19}$ - Table 1.

Table 1. Static and dynamic recidivism risk factors

\begin{tabular}{|c|c|c|}
\hline Category & Feature & Factor \\
\hline \multirow{6}{*}{ 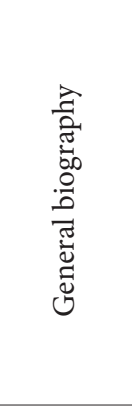 } & $\begin{array}{l}\text { Upbringing in a single-parent or foster family or children's } \\
\text { home }\end{array}$ & static \\
\hline & $\begin{array}{l}\text { No education or not higher than primary or incomplete pri- } \\
\text { mary education }\end{array}$ & dynamic \\
\hline & No professional qualifications & dynamic \\
\hline & $\begin{array}{l}\text { Unemployed below } 6 \text { months, } 6-12 \text { months, or longer than } 1 \\
\text { year }\end{array}$ & static \\
\hline & Non-believer or religiously indifferent & dynamic \\
\hline & Released after serving the full sentence & static \\
\hline \multirow{7}{*}{ 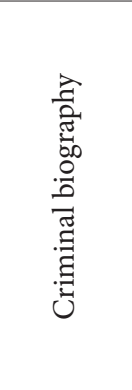 } & One, two, three or more than three police records & static \\
\hline & Stay at a juvenile correction facility & static \\
\hline & Sentenced to restriction of liberty & static \\
\hline & $\begin{array}{l}\text { Suspended/unsuspended sentence up to } 3 \text { years, unsuspended } \\
\text { sentence over } 3 \text { years }\end{array}$ & static \\
\hline & Unintentional crime & static \\
\hline & Accessory to a crime & static \\
\hline & Independent intentional crime & static \\
\hline \multirow{5}{*}{ 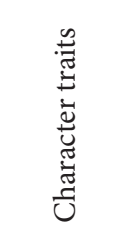 } & Does not accept his/her social situation & dynamic \\
\hline & Contempt for the environment & dynamic \\
\hline & Suspicion, distrust & dynamic \\
\hline & Destructive tendencies & dynamic \\
\hline & Emotional instability - impulsiveness & dynamic \\
\hline
\end{tabular}

19 Hołyst, “Skala Prognostyczna..., 39. 


\begin{tabular}{|c|c|c|}
\hline \multirow{4}{*}{ 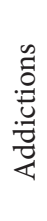 } & Alcohol & dynamic \\
\hline & Drugs & dynamic \\
\hline & Gambling & dynamic \\
\hline & Other & dynamic \\
\hline \multirow{9}{*}{ 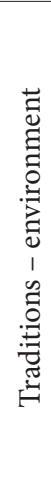 } & Both parents unqualified & static \\
\hline & Both parents with below primary education & static \\
\hline & Both parents non-believers or religiously indifferent & static \\
\hline & Father with a suspended sentence or sentences & static \\
\hline & Mother with a suspended sentence or sentences & static \\
\hline & Father with an unsuspended sentence & static \\
\hline & Mother with an unsuspended sentence & static \\
\hline & $\begin{array}{l}\text { Other relations (one or more) with a suspended sentence or } \\
\text { sentences }\end{array}$ & static \\
\hline & Other relations with unsuspended sentences & static \\
\hline
\end{tabular}

Source: Criminal Behaviour Risk Assessment Forecasting Scale (SPORPZP) developed by Brunon Hołyst, p. 39.

Classification to one of the three risk groups will be made according to the raw point score calculated based on the information received from probation officers for each probationer. According to the Brunon Hołyst's recommendations, a certain number of points was assigned to each risk factor.

The survey was conducted among 60 probation officers, of which $40 \%$ are professional officers and $60 \%$ are volunteers. The majority of them $(83 \%)$ are women. The dominating age intervals are $41-50$ years (35\%) and $30-40$ years (28\%). The mean age among the probation officers included in the survey was 45 years. Majority of probation officers had master's degree in pedagogics (55\%). 33\% of the surveyed population had degree in resocialization, $10 \%$ had degree in psychology, and 7\% in sociology. The seniority in professional and pedagogical career varied among the probation officers participating in the survey. $90 \%$ of the respondents had more than 10-year seniority. The mean, general professional seniority in the surveyed group was 21 years. $48 \%$ of the surveyed population have worked as a probation officer for more than 10 years, and 13\% for more than 20 years. $18 \%$ of probation officers have less than 5-year seniority in this position. The mean seniority as a probation officer was 12 years.

The group studied for static and dynamic recidivism risk factors included 60 probationers, all of them males. The dominating age was under 30 years $(47 \%)$ and from 31 to 40 years (33\%). The mean age of probationers was 34 years. The majority were bachelors (57\%), only one in five (22\%) was married. They predominantly live in cities (78\%). $58 \%$ of the studied probationers live in cities 
with more than 50 thousand population, and only $22 \%$ live in the country. The described probationers committed common crimes (57\%) and violent crimes (43\%). The remaining features of criminal biography and family environment of the probationers will be presented further in the paper.

\section{Interpretation of Obtained Results}

The first part of the analysis of the collected empirical material involved the characteristics of the selected biography features of the probationers. The probation officers provided the information on static features related to the upbringing in a single-parent of foster family or children's home, and experienced unemployment before being put under probation. In addition, certain dynamic features were analysed, such as low level of education and absence of professional qualifications. The information from penitentiaries about serving the full sentence was also included, so were religious features. These are criteria which according to Brunon Hołyst increase the likelihood of future criminal behaviour.

The collected information indicates that the vast majority of probationers were raised in the two-parent family (75\%). Only one in five probationers (20\%) was raised in a single-parent family or a foster family, and only three offenders (5\%) stayed in a children's home. The next analysed feature was unemployment. It turned out that only $13 \%$ of probationers had been unemployed for one year, and $7 \%$ for longer than one year. In terms of the analysed dynamic features concerning the general biography, the education of the offenders was considered. The probationers had mostly vocational education (33\%), primary education (20\%) and secondary education (20\%). Only 5 offenders in the group had college degrees $(8 \%)$. No probationer was classified as no education or not higher than primary or incomplete primary education. Then, in the group of dynamic features, the professional qualifications of the probationers were considered. The collected information indicates that absence of qualifications for a specific profession was found in $31 \%$ of the probationers. In addition, $40 \%$ of the convicts had been in a penitentiary before being put under probation. Only one of them however was released after serving the full sentence. The last feature described by the probation officers was whether the probationer is a believer, non-believer or religiously indifferent. Although the survey was anonymous, $42 \%$ of probation officers said that such question went too deep into the privacy sphere of the probationers supervised by them and refused to give information. Finally, the collected data indicate that the religiously indifferent subgroup included $28 \%$ of the described probationers. To summarize, it can be said that in terms of analysed static features of general biography that increase the likelihood of future criminal behaviour one should consider the upbringing of the one fifth of the probationers in a single-parent family or a foster family (20\%). Also, one in five probationers $(20 \%)$ 
experienced unemployment with a resulting significant stress and the feeling of social exclusion.

In the group of analysed dynamic features, the probation officers working with probationers should pay a special attention to the absence of qualifications for a specific profession (found in one third of the probationers) and the experience caused by a previous stay in a penitentiary which can have a negative or even a destructive impact on the psychological condition of probationers and be connected with the assimilation of the prison subculture rules. An important supplement of the presented biographical data can be the analysis of selected static features of the family environment, taking into account the convictions of the parents and the closest relations, and the information related to education, professional qualifications or religious awareness of the parents. These features can have an important impact on asocial behaviours and criminogenesis among the probationers. However, when asked about such features the probation officers usually could not provide any information on the family environment of the probationers, explaining that their probationers are adults. From among sixty probation officers participating in the survey, more than $40 \%$ did not have basic information on the important socio-pedagogical features of the probationers' parents. The obtained fragmentary information indicates that only 20 fathers $(20 \%)$ and 9 mothers (15\%) of the probationers had sentences (suspended or unsuspended). 6 people (10\%) from among probationers' relations were convicted for committed offences. In two cases the probation officers found out that both parents are unqualified (3\%). In addition, it was determined that $27 \%$ of the parents are non-believers or religiously indifferent. No education level below primary was found among the parents of the described probationers. It is surprising that the surveyed probation officers were not interested in finding out the dysfunctional or criminogenic features of the family environment which could have had a decisive connections with the criminal demoralization process of their probationers. It is all the more strange because $47 \%$ of the probationers still live with their parents. Then, the analysis covered the selected static criminogenic features related to the criminal biography of probationers (Table 2).

Table 2. Features of probationers' criminal biography

\begin{tabular}{|l|c|c|}
\hline \multirow{2}{*}{\multicolumn{1}{|c|}{ Features }} & \multicolumn{2}{c|}{ Probationers } \\
\cline { 2 - 3 } & /n=60/ \\
\cline { 2 - 3 } & N & $\%$ \\
\hline One police record & 21 & 35 \\
\hline Had a suspended sentence & 18 & 30 \\
\hline Two or three police records & 14 & 23 \\
\hline More than three police records & 10 & 17 \\
\hline
\end{tabular}




\begin{tabular}{|l|c|c|}
\hline Unsuspended sentence over 3 years & 7 & 12 \\
\hline Unsuspended sentence up to 3 years & 6 & 10 \\
\hline Committed an independent intentional crime & 6 & 10 \\
\hline Sentenced to restriction of liberty & 4 & 7 \\
\hline Committed an unintentional crime & 3 & 5 \\
\hline Accessory to a crime & 3 & 5 \\
\hline Stayed at a juvenile correction facility & 1 & 2 \\
\hline
\end{tabular}

Note: the sum is not $100 \%$.

Source: autor's own study.

The data presented in the Table 2 indicate that $35 \%$ of probationers had one police record, a 30\% received suspended sentences. More than one fifth of offenders had two or three police records (23\%). In addition, the probation officers must pay a special attention to the probationers who had more than three police records (17\%) and the people who have received unsuspended sentences over 3 years (12\%) and unsuspended sentences up to 3 years (10\%). Particularly important for the successful probation is the fact that only one probationer stayed at a juvenile correction facility when he was a minor.

Generally, it can be said that the described list of criminal biography features of the probationers does not indicate a particularly deep criminal demoralization because only $40 \%$ of the offenders had more than two police records before the probation was ordered.

Then, the probation officers were asked to describe selected character traits shown by their probationers in social relations. The officers could check which trait manifests itself discernibly and which strikingly. The observations of probation officers suggest that almost one third of the probationers in their social relations strikingly demonstrate suspicion and distrust (28\%) and emotional instability - impulsiveness (27\%). In addition, the probation officers see lack of acceptance of his social position in more than one fifth of the probationers (23\%). On the other hand, only a few of them showed contempt for the environment $(10 \%)$ and destructive tendencies (7\%). To round up, let us mention that the probation officers did not see any indications of destructive tendencies in $45 \%$ of the probationers and any symptoms of contempt for the environment in $40 \%$ of them. The indicated traits can particularly affect the social integration process of probationers in the community and the safety of people in their closest environment. Establishing and maintaining positive, bond-based social relations by probationers with significant people in the local community is an important condition of a successful resocialization in conditions of supervised liberty. It is the probation officers who should provide a particular control, care and support to those probationers who openly manifest negative or even destructive social 
behaviours. An appropriate identification of such manifestations will make it easier for the probation officers to effectively plan preventive and corrective actions addressed to such probationers and will increase the public security. It must be noted here that the description of the probationer's character traits by the probation officers should be treated with high caution because the traits taken from the Brunon Hołyst's SPORPZP scale were defined in such a manner as to be easily recognizable using the Rorschach test. This study used only the presentation of probation officers' statements about their probationers, that is the analysis of inference indicators. The supplementary studies with the use of standardized techniques for determination of character traits will be presented in another paper.

Next, the probation officers were asked for information about the basic addictions of their probationers, that is dynamic factors which can be related to their recidivism. The provided information indicates that the probation officers observed a strong addition to alcohol in $25 \%$ of the probationers, and the moderate addiction in $40 \%$. However, $45 \%$ of the probationers did not show tendencies to a risky contact with alcohol. In addition, it turned out that the described group of offenders, in the opinion of probation officers, included 7 strong drug addicts (12\%), and 8 moderate drug addicts (13\%). The vast majority (75\%) of probationers did not have any symptoms of contacts with drugs. In addition to the addiction to toxic substances, the probation officers indicated a strong addition to gambling among the probationers. The said behavioural addiction was strong in case of 3 probationers (5\%), and moderate in case of 2 (3\%). Out of other addictions, the probation officers noticed a tendency to overuse medicines which was moderate and strong in 5 probationers $(8 \%)$. As expected, an important criminogenic factor in this group was a risky contact with alcohol which affects more than a half of the evaluated probationers. In some cases, the alcohol addiction was accompanied with a risky contact with drugs which was observed by the probation officers in one fourth of the probationers.

Generally, the probation officers could speak about the static and dynamic criminogenic factors listed in the Criminal Behaviour Risk Assessment Forecasting Scale (SPORPZP) developed by Brunon Hołyst ${ }^{20}$. A point score were assigned to each factor. A probationer could get maximum 52 points. Using the $1 / 3$ method, the following recidivism risk intervals were defined. Total score from 0 to 18 points: low risk (group A), total score from 19 to 35 points: moderate risk (group B), total score from 36 to 52 points: high risk (group C). In addition to the classification based on the criminological forecast, the probation officers could indicate the risk group to which each described probationer would be classified based on the formal and legal criteria defined in the Ministry of Justice documents. Table 3 presents the results of classification of probationers to the three risk groups based on the above-mentioned criteria. 
Table 3. Classification of probationer to the recidivism risk groups

\begin{tabular}{|c|c|c|c|c|c|}
\hline \multirow[t]{2}{*}{ Risk group } & \multicolumn{2}{|c|}{$\begin{array}{l}\text { Criminological forecast } \\
\qquad / \mathrm{n}=60 /\end{array}$} & \multicolumn{2}{|c|}{$\begin{array}{c}\text { Formal and } \\
\text { legal criteria } \\
/ \mathrm{n}=60 /\end{array}$} & \multirow[t]{2}{*}{$\begin{array}{c}\text { Difference } \\
\%\end{array}$} \\
\hline & $\mathbf{N}$ & $\%$ & $\mathbf{N}$ & $\%$ & \\
\hline low risk $(\mathrm{A})$ & 27 & 45 & 15 & 25 & 20 \\
\hline moderate risk (B) & 33 & 55 & 25 & 42 & 13 \\
\hline high risk $(\mathrm{C})$ & 0 & 0 & 20 & 33 & -33 \\
\hline
\end{tabular}

Source: author's own study.

The data presented in Table 3 indicate that based on the criminological forecast which takes into consideration the measurement of selected static and dynamic factors, $55 \%$ of the probationers would be classified as moderate risk, and $45 \%$ as low risk of recidivism. None of the probationers would be classified as high risk of recidivism. On the other hand, when the probation officers used the classification based on the risk factors included in the formal and legal documents without the support of diagnostic tools, the dominating groups were moderate risk (42\%) and high risk (33\%) of recidivism. Only one fourth of the probationers (25\%) were classified as low risk. The differences in classification to risk groups based on the criminological factors and on formal and legal criteria are statistically significant $(\mathrm{p}<0.001)$.

It turned out that when the probation officers make the risk assessment based on their knowledge and experience taking into account only the formal and legal criteria, a probationer is more likely to be classified as high risk of recidivism. On the other hand, when the probation officers analyse the risk factors included in the forecasting scale, the same probationer significantly more often will be classified as low risk of recidivism. It should be remembered that when classifying the probationers to risk groups the probation officers take into consideration 8 criteria listed in Art. 169a of Code of Corrections. A probationer is classified as group $A$ and $C$ when a premise from among those listed in $₫ 11.2$ and $₫ 11.3$ is identified. The sufficient criterion to be assigned to the basic risk level (group B) is the absence of a premise typical for other groups ( $\$ 11.4)$. The criteria included in the mentioned Code relate mainly to the assessment of static risk factors, that is the premises which took place in the past. These are: basic and multiple recidivism, similar offences committed after the sentence, sexual crimes, psychical disorders, previous convictions and way of life. In addition, the probation officers 
can also take into account dynamic factors such as addition to alcohol, narcotics or psychotropic substances, domestic violence, links with criminal subculture. The list of these criteria is very short and the classification proposed by this model is not based on the risk probability measurement as in case of the procedures based on measurement tools of the second, third and fourth generation used to identify the presence and the strength of objective risk factors in a specific situation of a probationer using the actuarial approach. In practice, a probation officer can classify a probationer to the selected risk group based on the occurrence of one of the listed risk factors, which according to Mariusz Sztuka ${ }^{21}$ is unprecedented in the contemporary recidivism risk management.

\section{Summary of the Study Results}

In the risk management model, the effectiveness of probation officer actions depends on the probationer's features, intensity o criminogenic factors, and quality of the environment in which the probationer is functioning. In the described output model the probation officer's task is to collect information about the risk of recidivism ad then to profile the probationers in terms of forecast risk of recidivism. The accurate classification of probationers to specific risk groups will help the probation officer in planning the resocialization actions ${ }^{22}$. According to the $\mathrm{R}-\mathrm{N}-\mathrm{R}$ model, the correction programmes should be addressed to offenders who have many problem areas correlated with recidivism. However, when working with low-risk probationers, the probation officers must avoid excessive pressure and control similar to the one they use for the high-risk probationers because this can increase the symptoms of asocial behaviours and criminal demoralization. Unfortunately, the probation officers were not equipped with reliable measuring tools for classification of probationers. Taking this into account, in own studies for assessment of static and dynamic risk factors used were the indices developed by Brunon Hołyst for the Criminal Behaviour Risk Assessment Forecasting Scale $(\mathrm{SPORPZP})^{23}$. The probation officers assessed the recidivism risk factors based on their own observations resulting from the analysis of events prior to the criminal act committed by the probationer (case anamnesis) and observable manifestations indicating that the probationer ripens to be an offender (case catamnesis). It turned out that, focused on the current control of their probationers, the probation officers collect very little information on the static risk factors, that is empirical predictors of future criminal behaviours. However, the authors of the R-N-R

\footnotetext{
21 Sztuka, "Szacowanie ryzyka...".

22 Barbara Stańdo-Kawecka, "Wybrane problemy...."

23 Hołyst, "Skala Prognostyczna...”.
} 
model claim that the correct selection and accurate estimation of these factors determines a successful resocialization in conditions of supervised liberty ${ }^{24}$.

The probation officers were not prepared to recognize the criminogenic needs of the probationers. When formulating the criminological forecast, they use a very limited list of predictors of the future criminal behaviour of the probationers, based on the information included in court files and subjective opinions. The probation officers were not equipped by the judiciary with standardized tools allowing them to determine the statistical probability of the next crime being committed by a given offender. Consequently, the collected empirical data indicate that the classification of probationers to the recidivism risk groups by probation officers based on the formal and legal criteria is significantly different than the classification on the basis of static and dynamic risk factors based on individual criminological prediction.

The performed research-based analyses indicate that the classification model for probationers implemented in the Ministry of Justice and based on the identification of one of the listed risk factors results in a significantly greater statistical probability of a restrictive classification to a high recidivism risk group, and thus exclusion of a probationer from the open environment and incarceration. In this manner, the probation methodology can shift from educational purposes to prevention and control. This is very likely taking into account a limited resocialization offer in the form of developed and proven and effective resocialization programmes that can be used by probation officers in their work with probationers in the open environment and the limited specialization of probation officers necessary for work with a probationer with many recognized criminogenic needs ${ }^{25}$.

Kategoryzacja skazanych oddanych pod dozór kuratora sądowego do grup ryzyka przestępczości powrotnej na podstawie czynników kryminogennych

Streszczenie: W artykule na podstawie badań przekrojowych przeprowadzono ocenę zasad kwalifikacji do grup ryzyka osób skazanych objętych dozorem kuratora sądowego. Zaklasyfikowanie osób dozorowanych do grup ryzyka ma na celu poprawę bezpieczeństwa publicznego i dostosowanie rodzaju i intensywności oddziaływań kuratorów do profilu skazanych. W ten sposób powstaje możliwość dostosowania metodycznych oddziaływań kuratorów sądowych do strategii pracy ogólnoświatowych służb probacyjnych opartych na modelu zarządzania przypadkiem (case management). Przyjęte rozwiązania są zgodne z Wzorcowymi regułami minimalnymi Narodów Zjednoczonych (tzw. zasady tokijskie) oraz standardami zawartymi w europejskich regułach probacyjnych.

Słowa kluczowe: kuratorzy sądowi, osoby dozorowane, grupy ryzyka przestępczości powrotnej

24 Andrews, Bonta, Hoge, "Classification...”.

25 Łukasz Wirkus, Wybrane programy resocjalizacyjne w praktyce kuratorów sądowych (Toruń: Wydawnictwo Adam Marszałek, 2017). 


\section{References}

Andrews, Donald, Bonta, James. The Psychology of Criminal Conduct. New Providence: Lexis-Nexis, 2010.

Andrews, Donald, Bonta, James, Hoge, Robert. "Classification for Effective Rehabilitation. Rediscovering Psychology”. Criminal Justice and Behavior 17 (1990), 19-52.

Bałandynowicz, Andrzej, "Reintegracja społeczna skazanych wsparta na paradygmacie tożsamości osobowej, społecznej i kulturowo-cywilizacyjnej”. Niepetnosprawność 8 (2012), 9-39.

Barczykowska, Agnieszka, Dzierżyńska-Breś, Sonia. "Profilaktyka oparta na wynikach badań naukowych (evidence based practice)". Resocjalizacja Polska 4 (2013), 131-152.

Barczykowska, Agnieszka, Dzierżyńska-Breś, Sonia, Muskała, Maciej. Systemy oddziaływań resocjalizacyjnych Anglii i Stanów Zjednoczonych Ameryki. Poznań: Wydawnictwo Naukowe UAM, 2015.

Dziadkiewicz, Krzysztof. "Kategoryzacja skazanych oddanych pod dozór kuratora sądowego w świetle aktualnych zmian prawa karnego wykonawczego i przesłanek praktycznych stosowania taksonomii w pracy ze skazanym pozostającym w okresie próby". In: Resocjalizacja - czarno na białym, eds. Anna Karłyk-Ćwik, Dorota Rybczyńska-Abel. Toruń: Wydawnictwo Edukacyjne Akapit, 2016, 176-189.

Hołyst, Brunon. "Podstawy i zakres indywidualnej prognozy kryminologicznej”. Probacja 1 (2013), 5-28.

Hołyst, Brunon. "Skala Prognostyczna do Oceny Ryzyka Podjęcia Zachowań Przestępczych - indywidualna predykcja kryminologiczna”. Probacja 2 (2013), 39-45.

Kordik, Andrzej. Warunkowe zawieszenie wykonania kary w systemie środków probacyjnych i jego efektywność. Wrocław: Drukarnia Kwant, 1998.

Marek, Andrzej. Prawo karne. Warszawa: Wydawnictwo C.H. Beck, 2006.

Muskała, Maciej. “Służba kuratorska w Anglii i Walii”. Probacja 1 (2015), 51-66.

Ostrihanska, Zofia. "Diagnoza w pracy kuratora sądowego”. In: Zarys metodyki pracy kuratora sądowego, eds. Tadeusz Jedynak, Krzysztof Stasiak. Warszawa: Wolters Kluwer, 2008, 171-193.

Skupiński, Jan. Warunkowe skazanie w prawie polskim na tle porównawczym. Warszawa: Oficyna Naukowa, 1992.

Smrokowska-Reichmann, Agnieszka. "Amerykański Case Management - wzorzec dla reform systemu pomocy społecznej w Polsce?”. Wspólne Tematy 10 (2009), 3-9.

Stańdo-Kawecka, Barbara. "Ruch What works i 'nowa resocjalizacja' - nowa perspektywa w polityce karnej?”. In: Węzłowe problemy prawa karnego, kryminologii i polityki kryminalnej. Ksiega pamiatkowa ofiarowana Profesorowi Andrzejowi Markowi, eds. Violeta Konarska-Wrzosek, Jerzy Lachowski, Jerzy Wójcikiewicz. Warszawa: Wydawnictwo Wolters-Kluwer, 2010, 891-907.

Stańdo-Kawecka, Barbara. "Wybrane problemy profesjonalizacji organów probacyjnych i klasyfikacji sprawców oddanych pod dozór do grup ryzyka”. Nowa Kodyfikacja Prawa Karnego XXXIII. Acta Universitatis Wratislaviensis 3617 (2014), 12-39.

Szczygieł, Grażyna. "Środki alternatywne wobec kary pozbawienia wolności”. Nowa Kodyfikacja Prawa Karnego XXXIII. Acta Universitatis Wratislaviensis 3617 (2014), 42-70.

Sztuka, Mariusz. Anachronizm i aktualność. Idea resocjalizacji w sporze o nowoczesność. Kraków: Wydawnictwo Uniwersytetu Jagiellońskiego, 2013.

Sztuka, Mariusz. "Szacowanie ryzyka w pracy kuratora. Polskie rozwiązania i ich odpowiedniki w rozwiniętych systemach zachodnich”. In: Polska kuratela sądowa na przełomie wieków. Nadzieje, oczekiwania, dylematy, redakcja naukowa, eds. Marek Konopczyński, Łukasz Kwadrans, Krzysztof Stasiak. Kraków: Oficyna Wydawnicza “Impuls", 2016, 79-92. 
Węgliński, Andrzej. "Resocjalizacja w środowisku otwartym z zastosowaniem metody zarządzania przypadkiem w dozorach kuratorskich". In: Współczesne dylematy resocjalizacyjne - $w$ strone twórczej resocjalizacji, eds. Wiesław Ambrozik, Anna Kieszkowska, Krzysztof Sawicki. Kraków: Oficyna Wydawnicza “Impuls”, 2018, 409-418.

Węgliński, Andrzej, Kuziora, Grażyna. W poszukiwaniu wychowującej kurateli sądowej. Lublin: Wydawnictwo UMCS, 2016.

Wirkus, Łukasz. Wybrane programy resocjalizacyjne w praktyce kuratorów sądowych. Toruń: Wydawnictwo Adam Marszałek, 2017.

Wójcik, Dobrochna. "Stosowanie w postępowaniu karnym narzędzi diagnostyczno-prognostycznych stużących oszacowaniu ryzyka powrotności do przestępstwa”. Prawo w Działaniu. Sprawy Karne 16 (2013), 59-102.

Wykaz aktów prawnych:

Rozporządzenia Ministra Sprawiedliwości z dnia 13 czerwca 2016 r. w sprawie sposobu i trybu wykonywania czynności przez kuratorów sądowych w sprawach karnych wykonawczych, poz. 969.

Rozporządzenia Ministra Sprawiedliwości z dnia 26 lutego 2013 r. w sprawie sposobu wykonywania obowiązków i uprawnień przez kuratorów sądowych w sprawach karnych wykonawczych, poz. 335 .

Ustawa - kodeks karny wykonawczy (Dz.U. 1997, nr 90, poz. 557). 